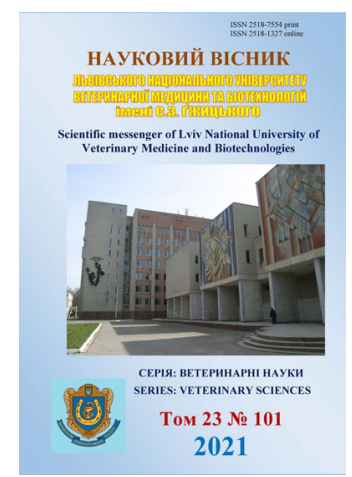

\author{
Науковий вісник Яьвівського націонадьного університету \\ ветеринарної медицини та біотехнологій імені С.3. Гжицького. \\ Серія: Ветеринарні науки \\ Scientific Messenger of Lviv National University \\ of Veterinary Medicine and Biotechnologies. \\ Series: Veterinary sciences
}

\title{
The activity of the enzyme link of the antioxidant defense system of cows organism in experimental fasciolosis
}

\author{
D. V. Frejuk, V. V. Stybel
}

Stepan Gzhytskyj National University of Veterinary Medicine and Biotechnologies Lviv, Ukraine

Article info

Received 01.12.2020

Received in revised form 04.01 .2021

Accepted 05.01.2021

Stepan Gzhytskyi National University of Veterinary Medicine and Biotechnologies Lviv, Pekarskaya Str., 50, Lviv, 79010, Ukraine.

Tel.: +38-097-448-24-11

E-mail:frejukdima@gmail.com
Frejuk, D. V., \& Stybel, V. V. (2021). The activity of the enzyme link of the antioxidant defense system of cows organism in experimental fasciolosis. Scientific Messenger of Lviv National University of Veterinary Medicine and Biotechnologies. Series: Veterinary sciences, 23(101), 3-7. doi: $10.32718 /$ nvlvet10101

The antioxidant defense system of the organism controls and inhibits all stages of free radical reactions, starting from their initiation and ending to the formation of hydroperoxides and TBA-active products. The main mechanism of control of these reactions is associated with the chain of reversible redox reactions of metal ions, glutathione, ascorbate, tocopherol and other substances, the value of which is especially important for the preservation of long-standing macromolecules of nucleic acids and proteins, some components of membranes. The purpose of the research was to investigate the activity of the enzyme link of the antioxidant defense system of cows organism in experimental fasciolosis. Twelve cows of 4-5 years of age, Black-Spotted breed, were selected for the experiments, from which 2 groups were formed, six animals in each. Animals in control group $(C)$ were clinically healthy. Animals of experimental group (E) were experimentally infected with adolescents. During the research, the rules of compulsory experiments were followed - selection and keeping of analogue animals in groups. The cows' ration was balanced in terms of nutrients and minerals. All animal manipulations were carried out in accordance with the European Convention for the Protection of Vertebrate Animals, which are used for experimental and scientific purposes. According to the results of our research, in cows affected by fasciolosis invasion, catalase activity in their blood decreased by $21.5 \%$, and superoxide dismutase activity by $30 \%$. In the research of the glutathione link of the antioxidant defense system, it was found that the activity of both glutathione peroxidase and glutathione reductase is also reduced in experimental fasciolosis. Thus, on the 25th day of the experiment, a decrease in these enzymes by 26.6 and $20.5 \%$ is set. Thus, with the development of fasciolosis in ruminants, the balance in the complex "Antioxidant system - Lipid peroxidation" is disturbed, which in turn leads to complications of the disease. In the future it is planned to investigate the state of the non-enzymatic part of the antioxidant defense system of cows organism with experimental fasciolosis.

Key words: parasitology, fasciolosis, antioxidant defense system, enzymes, superoxide dismutase, catalase, glutathione peroxidase, glutathione reductase.

\section{Активність ензимної ланки системи антиоксидантного захисту організму корів за експериментального фасціольозу}

\author{
Д. В. Фреюк, В. В. Стибель
}

Львівський національний університет ветеринарної медицини та біотехнологій імені С. 3. Гжсиького, м. Львів, Україна

Антиоксидантна система захисту організму контролює і гальмує всі етапи вільнорадикальних реакцій, починаючи від їх ініціації $і$ закінчуючи утворенням гідроперекисів та ТБК-активних продуктів. Основний механізм контролю циих реакцій пов'язаний з ланцюгом оборотних окисно-відновних реакиій іонів металів, глутатіону, аскорбату, токоферолу та інших речовин, значення яких особливо важливо для збереження довго існуючих макромолекул нуклеїнових кислот і білків, деяких складових мембран. Метою 
роботи було дослідити активність ензимної ланки системи антиоксидантного захисту організму корів за експериментального фасиіольозу. Для дослідів було відібрано 12 корів 4-5-річного віку, чорно-рябої породи, з яких сформовано 2 групи, по шість тварин у кожній. Тварини контрольної групи (К) були клінічно здоровими. Тварини дослідної групи (Д) були експериментально заражені адолескаріями. За проведення досліджень дотримувалися правил, обов язкових щуодо виконання дослідів - підбору та утримання тварин-аналогів у групах. Раціон корів був збалансований за поживними та мінеральними речовинами. Усі маніпуляції з тваринами проводили відповідно до Свропейської конвенції про захист хребетних тварин, які використовуються для експериментальних $i$ наукових иілей. Як показали результати наших досліджень, у корів, які були ураженні фасиіольозною інвазією, активність каталази у їх крові знизилася на 21,5\%, а активність супероксиддисмутази - на 30 \%. При дослідженні глутатіонової ланки системи антиоксидантного захисту встаановлено, щзо за експериментального фасиіольозу знижується також активність $і$ глутатіонпероксидази та глутатіонредуктази. Так, на 25 добу досліду встановлено зниження вказаних ензимів на 26,6 і 20,5 \%. Таким чином, за розвитку фасиіольозу у жуйних тварин порушується рівновага у комплексі “Антиоксидантна система - Пероксидне окиснення ліпідів”, що у подальшому веде до ускладнення перебігу даного захворювання. У подальшому планується дослідити стан неензимної ланки системи антиоксидантного захисту організму корів за експериментального фасиіольозу.

Ключові слова: паразитологія, фасціольоз, система антиоксидантного захисту, ензими, супероксиддисмутаза, каталаза, глутатіонпероксидаза, глутатіонредуктаза.

\section{Вступ}

Наявність багатоступеневої антиоксидантної системи захисту клітини від вільнорадикального окиснення, яка склалася в ході філогенетичного розвитку, зумовлює складність причино-наслідкових відносин серед про- та антиоксидантами і направлена, в першу чергу, на встановлення балансу поміж ними, і внаслідок цього - збереження оптимального метаболічного балансу клітини (Varkholiak \& Gutyj, 2019; Lesyk et al., 2020; Said et al., 2020).

В основу захисту клітинних структур від ендогенних АФК покладено елімінацію первинних активних форм кисню у процесах якої насамперед беруть участь такі ензими системи антиоксидантного захисту, як супероксиддисмутаза, каталаза, а у знешкодженні екзогенних АФК основна роль належить глутатіонпероксидазам (Calabrese et al., 2005; Kulyaba et al., 2016; 2017; 2019; Lavryshyn et al., 2019; Varkholiak et al., 2020).

Згідно даних літератури відомо, що за дії на організм різних негативних факторів, реакції вільнорадикального окиснення у клітинах різко посилюються (Kausar et al., 2018; Cunha-Oliveira et al., 2020). При вільнорадикальному пероксидному окисненні, практично на всіх етапах, утворюється ряд продуктів, які $\epsilon$ результатом взаємодії вільних радикалів між собою, з біологічними макромолекулами (Martyshuk et al., 2019; Grymak et al., 2020). Важливо виділити, що посилене утворення первинних вільних радикалів $є$ побічним результатом зростання інтенсивності біохімічних реакцій у відповідь на дію екстремального фактоpa (Gutyj et al., 2017; Slivinska et al., 2020).

На основі попередніх досліджень нами встановлено, що за експериментального фасціольозу у корів паразити виділяють продукти метаболізму, які сприяють утворенню вільних радикалів, що у свою чергу посилюють ініціацію процесів пероксидного окиснення ліпідів. На це вказує зростання продуктів пероксидного окиснення ліпідів: дієнових кон'югатів, гідроперекисів ліпідів та ТБК-активних продуктів (Freiuk \& Stybel, 2020).

Саме тому метою роботи було дослідити активність ензимної ланки системи антиоксидантного захисту організму корів за експериментального фасціольозy

\section{Матеріал і методи досліджень}

Для дослідів було відібрано 12 корів 4-5-річного віку, чорно-рябої породи, з яких сформовано 2 групи, по шість тварин у кожній. Тварини контрольної групи (К) були клінічно здоровими. Тварини дослідної групи (Д) були експериментально заражені адолескаріями. За проведення досліджень дотримувалися правил, обов'язкових щодо виконання дослідів - підбору та утримання тварин-аналогів у групах. Раціон корів був збалансований за поживними та мінеральними речовинами.

Кров для аналізу брали з яремної вени до зараження та на 5-, 10-, 15-, 20-, 25- і 30-у добу досліду.

Визначення активності супероксиддисмутази проводили за методом Дубиніної Є. С. зі співр. Метод визначення полягає у відновленні нітросинього тетразолію супероксидними радикалами, які утворюються в реакції між феназинметасульфатом і відновленою формою нікотинамідаденіндинуклеотиду (Vlizlo, 2012).

Визначення каталазної активності проводили за методом Королюк М. А. та ін. Принцип методу базується на здатності пероксиду водню утворювати 3 солями молібдату стійкий кольоровий комплекс. Інтенсивність забарвлення вимірювали на СФ-26 за довжини хвилі $\lambda=410$ нм проти контрольної проби, у яку замість пероксиду водню вносили воду (Vlizlo, 2012).

Визначення активності глутатіонпероксидази проводили за методом В.В. Лемешко і співавт. Мірою активності глутатіонпероксидази (ГП) $є$ швидкість окиснення глутатіону при наявності гідроперекису третинного бутилу. Концентрацію відновленого глутатіону визначають до і після реакції колориметрично. В основі розвитку кольорової реакції лежить взаємодія SH-груп 3 5,5 -дитіобіс-2-нітробензойною кислотою (ДТНБК) з утворенням забарвленого продукту - тіонітрофенільного аніону (ТНФА). Вміст останнього прямо пропорційний кількості SH-груп, що прореагували з ДТНБК (Vlizlo, 2012).

Активність ГР визначали спектрофотометрично, за швидкістю відновлення глутатіону за наявності NADPH (Vlizlo, 2012).

Експериментальні дослідження проводили відповідно до Закону України "Про захист тварин від жор- 
стокого поводження" від 28.03.2006 р. та правил Свропейської конвенції захисту хребетних тварин, які використовуються в експериментальних та інших наукових цілях від 13.11.1987 p.

Аналіз результатів досліджень проводили за допомогою пакету програм Statistica 6.0. Вірогідність різниць оцінювали за t-критерієм Стьюдента. Результати середніх значень вважали статистично вірогідними при * - $\mathrm{P}<0,05, * *$ - $<<0,001$ (ANOVA).

\section{Результати та їх обговорення}

Для характеристики співвідношень між прооксидантними та антиоксидантними процесами в клітинах тварин за умов розвитку експериментального фасціольозу важливе значення має визначення ензимної активності системи антиоксидантного захисту організму тварин. До важливих показників антиоксидантного статусу клітин належить активність таких ензимів, як супероксиддисмутаза та каталаза. Дані ензими тісно пов'язані між собою. Згідно з сучасними уявленнями, суперексиддисмутаза виконує не так захисну роль, адже токсичність іiі субстрату супероксидного аніон-радикалу не дуже висока як джерела пероксиду водню, в результаті супероксиддисмутазної реакції, під дією якого може спостерігатися продукція гідроксильного радикалу та інактивація каталази.

Встановлено, що за розвитку фасціольозної інвазії у корів дослідної групи активність супероксиддисмутази на початку досліду становила $1,37 \pm 0,02$ у.о/мг білка. На 5 добу досліду у крові даної дослідної групи спостерігали незначне підвищення активності СОД, що можливо $\epsilon$ захисно-компенсаторною реакцією організму на розвиток фасціольозу та активації процесів пероксидного окиснення ліпідів.

\section{Таблиця 1}

Активність супероксиддисмутази у крові корів за експериментального фасціольозу $(\mathrm{M} \pm \mathrm{m}, \mathrm{n}=6)$

\begin{tabular}{ccc}
\hline \multirow{2}{*}{$\begin{array}{c}\text { Час дослідження } \\
\text { крові (доби) }\end{array}$} & \multicolumn{2}{c}{ СОД, у.о/мг білка } \\
\cline { 2 - 3 } & \multicolumn{2}{c}{ Групи тварин } \\
\hline До зараженняльна & Дослідна \\
5 доба & $1,40 \pm 0,02$ & $1,37 \pm 0,02$ \\
10 доба & $1,38 \pm 0,02$ & $1,41 \pm 0,02$ \\
15 доба & $1,37 \pm 0,03$ & $1,30 \pm 0,01$ \\
20 доба & $1,39 \pm 0,02$ & $1,21 \pm 0,04^{*}$ \\
25 доба & $1,36 \pm 0,03$ & $1,07 \pm 0,01^{* *}$ \\
30 доба & $1,40 \pm 0,03$ & $0,98 \pm 0,04^{* * *}$ \\
\hline
\end{tabular}

На 10 добу досліду у дослідної групи корів спостерігали зниження активності супероксиддисмутази, яка порівняно із контрольною групою знизилася на $5,1 \%$. На 15 і 20 доби досліду активність даного ензиму знижувалася відповідно на 12,9 і 21,3 \% відносно контролю. На 25 добу досліду активність супероксиддисмутази у крові корів дослідної групи становила $0,98 \pm 0,04$ у.о/мг білка тоді як у контрольної групи $1,40 \pm 0,03$ у.о/мг білка. На 30 добу досліду активність ензиму у крові інвазованих корів дещо підвищилася, однак порівняно 3 контролем була нижчою на 25,2 \% відповідно.

Каталаза $є$ ензимом класу оксидоредуктаз, який відновлює перекис водню до води і молекулярного кисню, компенсаторно підвищуючи коефіцієнт корисного використання екзогенного кисню в енергетичних цілях за рахунок часткового повернення в метаболічні ланцюги окисного фосфорилювання молекулярного кисню.

При дослідженні активності каталази у крові дослідних тварин встановлено незначне підвищення на 5 добу досліду, однак у подальшому активність каталази у крові інвазованих корів знижувалася. Зниження активності каталази спостерігали із 10 доби досліду, де відповідно даний показник у крові дослідної групи знизився на 5,5 \%. На 15 і 20 добу досліду активність ензиму у крові інвазованих корів вірогідно знизилася на 12,3 і 18,3 \% відносно контрольної групи (табл. 2).

\section{Таблиця 2}

Активність каталази у крові корів за експериментального фасціольозу $(\mathrm{M} \pm \mathrm{m}, \mathrm{n}=6)$

\begin{tabular}{ccc}
\hline \multirow{2}{*}{$\begin{array}{c}\text { Час дослідження } \\
\text { крові (доби) }\end{array}$} & \multicolumn{2}{c}{ КТ, мкат/л } \\
\cline { 2 - 3 } & Контрольна & Дослідна \\
\hline До зараження & $47,3 \pm 1,10$ & $47,4 \pm 1,13$ \\
5 доба & $47,2 \pm 1,15$ & $47,8 \pm 1,15$ \\
10 доба & $47,4 \pm 1,11$ & $44,8 \pm 1,14 *$ \\
15 доба & $47,2 \pm 1,10$ & $41,4 \pm 1,15^{* *}$ \\
20 доба & $47,3 \pm 1,13$ & $38,7 \pm 1,10^{* *}$ \\
25 доба & $47,4 \pm 1,15$ & $37,2 \pm 1,20^{* *}$ \\
30 доба & $47,3 \pm 1,12$ & $38,5 \pm 1,18^{* *}$ \\
\hline
\end{tabular}

На 25 добу досліду активність каталази у крові корів дослідної групи була найнижчою, де відповідно вона становила 37,2 \pm 1,20 мкат/л проти контролю $47,4 \pm 1,15$ мкат/л. На 30 добу досліду активність ензиму у крові інвазованих корів була нижчою на 18,6 \% порівняно з показниками контрольної групи корів.

Накопичення пероксиду водню через недостатню активність каталази в організмі інвазованих корів, в свою чергу, зумовлює появу гідропероксидів ліпідів, а також окиснювальної модифікації протеїнів.

Важливою системою антиоксидантного захисту організму корів за розвитку експериментального фасціольозу є глутатіонова система, до якої входить відновлений глутатіон та ензими: глутатіонпероксидаза i глутатіонредуктаза.

Відомо, що глутатіонпероксидаза в організмі тварин каталізує реакції перетворення пероксиду водню та гідропероксидів ліпідів до відповідних оксисполук, здійснюючи детоксикаційну функцію в клітинах. Таким чином, глутатіонпероксидаза гальмує процеси вільнорадикального окиснення та захищає плазматичні мембрани, внутрішньоклітинні структурні компоненти та біомолекули від пошкоджень під впливом токсичних метаболітів, які виділяють фасціоли.

Встановлено, що на початку досліду активність глутатіонпероксидази у крові контрольної та дослідної групи становила $35,6 \pm 1,05$ i $35,5 \pm 1,04$ нмоль 
NADPH/хв на 1мг білка. За розвитку експериментального фасціольозу спостерігаємо незначне підвищення активності ензиму на 5 добу досліду до $36,1 \pm 1,12$ нмоль NADPH/хв на 1мг білка. Однак у подальшому у крові корів дослідної групи спостерігали зниження активності даного ензиму, де відповідно на 10 і 15 доби досліду він знизився на 8,4 і 14,9\% відносно контролю (табл. 3).

\section{Таблиця 3}

Активність глутатіонпероксидази у крові корів за експериментального фасціольозу $(\mathrm{M} \pm \mathrm{m}, \mathrm{n}=6)$

\begin{tabular}{ccc}
\hline \multirow{2}{*}{$\begin{array}{c}\text { Час дослідження } \\
\text { крові (доби) }\end{array}$} & \multicolumn{2}{c}{ ГП, нмоль NADPH/хв на 1мг білка } \\
\cline { 2 - 3 } & \multicolumn{2}{c}{ Групи тварин } \\
\hline До зараженольна & Дослідна \\
5 доба & $35,6 \pm 1,05$ & $35,5 \pm 1,04$ \\
10 доба & $35,9 \pm 1,07$ & $36,1 \pm 1,12$ \\
15 доба & $35,7 \pm 1,10$ & $32,7 \pm 1,14$ \\
20 доба & $35,8 \pm 1,04$ & $30,3 \pm 1,10^{*}$ \\
25 доба & $35,7 \pm 1,06$ & $28,4 \pm 1,12^{* *}$ \\
30 доба & $35,8 \pm 1,05$ & $26,2 \pm 1,10^{* * *}$ \\
\hline
\end{tabular}

Найнижчою активність глутатінпероксидази була у крові інвазованих корів на 25 добу досліду, де відповідно вона знизилася на 26,6 \% відносно показників взятих у корів контрольної групи.

При дослідженні активності глутатіонредуктази встановлено аналогічні зміни як і у першому випадку. Так на 5 добу досліду активність глутатіонредуктази у крові дослідної групи тварин дещо зростала. Поступове зниження активності ензиму у крові дослідної групи корів спостерігали з 10 доби досліду, де порівняно 3 контрольною групою даний показник знизився на 5,3 \% відповідно (табл. 4).

\section{Таблиця 4}

Активність глутатіонредуктази у крові корів за експериментального фасціольозу $(\mathrm{M} \pm \mathrm{m}, \mathrm{n}=6)$

\begin{tabular}{ccc}
\hline \multirow{2}{*}{$\begin{array}{c}\text { Час дослідження } \\
\text { крові (доби) }\end{array}$} & \multicolumn{2}{c}{ ГР, нмоль NADPH/хв на 1мг білка } \\
\cline { 2 - 3 } & \multicolumn{2}{c}{ Групи тварин } \\
\hline До зараження & $1,52 \pm 0,04$ & Дослідна \\
5 доба & $1,49 \pm 0,03$ & $1,50 \pm 0,03$ \\
10 доба & $1,50 \pm 0,03$ & $1,42 \pm 0,04 *$ \\
15 доба & $1,53 \pm 0,04$ & $1,36 \pm 0,01^{*}$ \\
20 доба & $1,48 \pm 0,02$ & $1,29 \pm 0,03^{* *}$ \\
25 доба & $1,51 \pm 0,04$ & $1,20 \pm 0,01^{* * *}$ \\
30 доба & $1,50 \pm 0,03$ & $1,25 \pm 0,04^{* *}$ \\
\hline
\end{tabular}

На 15, 20 і 25 добу досліду активність глутатіонредуктази у крові інвазованих корів становила відповідно $1,36 \pm 0,01,1,29 \pm 0,03$ і $1,20 \pm 0,01$ нмоль NADPH/хв на 1мг білка, де порівняно 3 контролем даний показник був нижчим на 11,1, 12,8 і 20,5 \%.

Отже, гіпоензимемія зумовлена токсичним впливом фасціол на печінку та запуском вільнорадикального окиснення.

\section{Висновки}

За розвитку експериментального фасціольозу у корів пригнічується антиоксидантний статус їх організму на що вказує зниження активності каталази, супероксиддисмутази, глутатіонпероксидази та глутатіонредуктази. Таким чином, за розвитку фасціольозу у жуйних тварин порушується рівновага у комплексі "Антиоксидантна система - Пероксидне окиснення ліпідів”, що у подальшому веде до ускладнення перебігу даного захворювання.

Перспективи подальших досліджень. У подальшому планується дослідити стан неензимної ланки системи антиоксидантного захисту організму корів за експериментального фасціольозу.

Відомості про конфлікт інтересів. Автори стверджують про відсутність конфлікту інтересів щодо їх вкладу та результатів досліджень.

\section{References}

Calabrese, V., Lodi, R., Tonon, C., D'Agata, V., Sapienza, M., Scapagnini, G., Mangiameli, A., Pennisi, G., Stella, A. M., Butterfield, D. A. (2005). Oxidative stress, mitochondrial dysfunction and cellular stress response in Friedreich's ataxia. J Neurol Sci, 233(1-2), 145-162. doi: 10.1016/j.jns.2005.03.012.

Cunha-Oliveira, T., Montezinho, L., Mendes, C., Firuzi, O., Saso, L., Oliveira, P. J., \& Silva, F. S. G. (2020). Oxidative Stress in Amyotrophic Lateral Sclerosis: Pathophysiology and Opportunities for Pharmacological Intervention. Oxid Med Cell Longev, 2020, 5021694. doi: 10.1155/2020/5021694.

Freiuk, D. V., \& Stybel, V. V. (2020). The intensity of the processes of lipid peroxidation in the blood of cows in experimental fasciolosis. Scientific Messenger of Lviv National University of Veterinary Medicine and Biotechnologies. Series: Veterinary sciences, 22(100), 151-155. doi: 10.32718/nvlvet10025.

Grymak, Y., Skoromna, O., Stadnytska, O., Sobolev, O., Gutyj, B., Shalovylo, S., Hachak, Y., Grabovska, O., Bushueva, I., Denys, G., Hudyma, V., Pakholkiv, N., Jarochovich, I., Nahirniak, T., Pavliv, O., Farionik, T., \& Bratyuk, V. (2020). Influence of "Thireomagnile" and "Thyrioton" preparations on the antioxidant status of pregnant cows. Ukrainian Journal of Ecology, 10(1), 122-126. doi: 10.15421/2020_19.

Gutyj, B., Khariv, I., Binkevych, V., Binkevych, O., Levkivska, N., Levkivskyj, D., \& Vavrysevich, Y. (2017). Research on acute and chronic toxity of the experimental drug Amprolinsyl. Regulatory Mechanisms in Biosystems, 8(1), 41-45. doi: 10.15421/021708.

Kausar, S, Wang, F, \& Cui, H. (2018). The role of mitochondria in reactive oxygen species generation and Its implications for neurodegenerative diseases. Cells, 7(12), 274. doi: 10.3390/cells7120274.

Kulyaba, O. V., Stybel, V. V., \& Gutyj, B. V. (2016). The influence of clozaverm A and catozal on antioxidant status of cows organism for the experimental 
fasciolosis, sensitized atypical mycobacteria. Scientific Messenger LNUVMBT named after S. Z. Gzhytskyj, 18, 2(66), 96-99. doi: 10.15421/nvlvet6621.

Kulyaba, O., Stybel, V., \& Gutyj, B. (2017). The influence of closaverm a and catosal on indicators of protein synthesizing functions of cows liver by experimental fasciolosis, sentsitized by atypical mycobacteria. Scientific Messenger LNUVMBT named after S.Z. Gzhytskyj, 19(73), 122-125. doi: 10.15421/nvlvet7325.

Kulyaba, O., Stybel, V., Gutyj, B., Turko, I., Peleno, R., Turko, Ya., Golovach, P., Vishchur, V., Prijma, O., Mazur, I., Dutka, V., Todoriuk, V., Golub, O. Dmytriv, O., \& Oseredchuk, R. (2019). Effect of experimental fascioliasis on the protein synthesis function of cow liver. Ukrainian Journal of Ecology, 9(4), 612-615. URL: https://www.ujecology.com/articles/effect-ofexperimental-fascioliasis-on-the-protein-synthesisfunction-of-cow-liver.pdf.

Lavryshyn, Y. Y., Gutyj, B. V., Paziuk, I. S., Levkivska, N. D., Romanovych, M. S., Drach, M. P., \& Lisnyak, O. I. (2019). The effect of cadmium loading on the activity of the enzyme link of the glutathione system of bull organism. Scientific Messenger of Lviv National University of Veterinary Medicine and Biotechnologies. Series: Veterinary sciences, 21(95), 107 111. doi: 10.32718/nvlvet9520.

Lesyk, Y., Ivanytska, A., Kovalchuk, I., Monastyrska, S., Hoivanovych, N., Gutyj, B., Zhelavskyi, M., Hulai, O., Midyk, S., Yakubchak, O., \& Poltavchenko,T. (2020). Hematological parameters and content of lipids in tissues of the organism of rabbits according to the silicon connection. Ukrainian Journal of Ecology, 10(1), 30-36. doi: 10.15421/2020 5.

Martyshuk, T. V., Gutyj, B. V., Vishchur, O. I., \& Todoriuk, V. B. (2019). Biochemical indices of piglets blood under the action of feed additive "Butaselmevitplus". Ukrainian Journal of Veterinary and Agricultural Sciences, 2(2), 27-30. doi: 10.32718/ujvas2-2.06.

Said, W., Stybel, V., Gutyj, B., \& Prijma, O. (2020). Antioxidant protection system of dog organism at experimental toxocariasis. Bulletin of Poltava State Agrarian Academy, 3, 233-240. doi: 10.31210/visnyk2020.03.27.

Slivinska, L. G., Shcherbatyy, A. R., Lukashchuk, B. O., \& Gutyj, B. V. (2020). The state of antioxidant protection system in cows under the influence of heavy metals. Regulatory Mechanisms in Biosystems, 11(2), 237-242. doi:10.15421/022035.

Varkholiak, I. S., \& Gutyj, B. V. (2019). Influence of the preparation "Bendamin" on the indicators of antioxidant protection of rat myocardium in experimental modeling of heart failure. Scientific Messenger of Lviv National University of Veterinary Medicine and Biotechnologies. Series: Veterinary sciences, 21(95), 98-101. doi: 10.32718/nvlvet9518.

Varkholiak, I., Gutyj, B., \& Leskiv, Kh. (2020). Influence of "Bendamin" on the indices of antioxidant protection in rat's blood by an experimental doxorubicininduced cardiomyopathy. Scientific Light, 35, 41-44.

Vlizlo, V. V. (2012). Laboratorni metody doslidzhen u biologiyi, tvarynnycztvi ta veterynarnij medycyni: dovidnyk. Lviv: Spolom (in Ukrainian). 